\title{
Mass Incarceration Retards Racial Integration Peter Temin*
}

\section{Working Paper No. 155}

\author{
April 8, 2021
}

\begin{abstract}
President Nixon replaced President Johnson's War on Poverty with his War on Drugs in 1971. This new drug war was expanded by President Reagan and others to create mass incarceration. The United States currently has a higher percentage of its citizens incarcerated than any other industrial country. Although Blacks are only 13 percent of the population, they are 40 percent of the incarcerated. The literatures on the causes and effects of mass incarceration are largely distinct, and I combine them to show the effects of mass incarceration on racial integration. Racial prejudice produced mass incarceration, and mass incarceration now retards racial integration.
\end{abstract}

\section{https://doi.org/10.36687/inetwp155}

JEL Codes: J15, H720, K14, N11

Keywords: mass incarceration, War on Drugs, racism, neighborhood effects, Head Start

\footnotetext{
* Department of Economics, MIT, and NBER (ptemin@mit.edu). I thank Robert Solow for help with the underlying model of mass incarceration. This paper was supported by the Institute for New Economic Thinking. Contact: ptemin@mit.edu.
} 


\section{Mass Incarceration}

Mass incarceration is a major problem of the United States today that is largely invisible. Prisons are located in rural areas to save money and provide rural jobs, and the effects of mass incarceration are largely ignored in political and social discussions. How many people know that one out of three African American men will go to prison at today's incarceration rates? And how many children in urban public education are distracted by having a parent or a friend's parent in prison? This paper sheds light on this unseen problem by means of an economic model that implies that we have moved from one equilibrium position to another, from limited incarceration to mass incarceration (Bonczar, 2003; Johnson, 2009; Temin, 2018.)

David Garland defined mass incarceration as a rate of incarceration markedly above the level of comparable societies, that is, the systematic imprisonment of whole groups of the population. In the United States, this group is young Black males in urban environments. The rate of incarceration in the United States shown in Figure 1 stayed near one hundred people per 100,000 residents from 1925 to around 1980. The incarceration rate then rose rapidly for the next thirty years, reaching apparent stability after 2000. The incarceration rate in the European Union, Canada and Mexico stayed near the American rate before 1980, and the American incarceration rate now is the highest in the developed world, beating even Russia's incarceration rate (Raphael and Stoll, 2013, 5-10; Carson and Anderson, 2016; Garland, 2001).

I present a model of mass incarceration in the next section to show how we went from imprisonment rates similar to other developed countries to mass incarceration. I use the model to explain what happened in the history of this shift in the following section. I then survey recent economic analyses about where we are going today, and I close with the choices we face and the outlook ahead. I have two points to make in this paper. First, mass incarceration intensified segregation in the past half century. Second, while slavery helped the antebellum white economy, mass incarceration now retards economic growth by diverting state government funding from education to imprisonment (Temin, 2018).

\section{Theory}

The ideas in my model initially came from a statistical analysis of New York City: "The racialspatial concentration of incarceration in disadvantaged urban neighborhoods in New York accrued rapidly in the late 1980s and was sustained through the decade of the 1990s even as crime rates fell by one half or more. When high incarceration rates are internalized into the ecology of small, homogeneous neighborhoods, it adversely affects their economic fortunes, political participation, family life, and normative orientation (Fagan, West and Holland, 2004)." A noted criminologist, Todd Clear, articulated the implications of these statistical results. He argued that the growth of mass incarceration disrupted families, social networks and other forms of social support. The collateral effects of high rates of incarceration contribute to more- not less - crime. The resulting crime fuels a public call for ever-tougher responses to crime that generates new supplies of penal subjects. 
As Clear said: "Imprisonment in America is concentrated among young, poor — dominantly minority - men and (to a lesser extent) women who come from impoverished communities. The way these young people cycle through our system of prisons and jails, then back into the community, leaves considerable collateral damage in its wake. Families are disrupted, social networks and other forms of social support are weakened, health is endangered, labor markets are thinned, and - more important than anything else - children are put at risk of the depleted human and social capital that promotes delinquency. After a certain point, the collateral effects of these high rates of incarceration seem to contribute to more crime in these places. Crime fuels a public call for ever-tougher responses to crime. The increasing way in which the face of criminality is the face of person of color contributes to an unarticulated public sense that race and crime are closely linked. The politics of race and justice coexist malignantly, sustaining an evergrowing policy base that guarantees new supplies of penal subjects in a self-sustaining and selfjustifying manner (Clear, 2007, 175)."

Clear's analysis implies that the responsiveness of crime to incarceration is not linear. If we graph crime, "c," as a function of incarceration, "i," it will not be a straight line. Starting from little incarceration, the effect of increasing " $i$ " will be a negative-sloping line. Incarceration decreases crime. But Clear argued that the line was not linear. As incarceration increases, the slope of this line is reduced and then replaced by an upward-sloping line as more people serve time in prisons. Incarceration increases crime when incarceration is high. The left-hand side of Figure 2 shows what this looks like, a curving line looking like a broad "U."

At this stage, the relationship between crime and incarceration appears to be quadratic. But this cannot be the whole story as normal incarceration turns into mass incarceration because the people who are most likely to commit crimes are more likely be in prison when more young men are incarcerated. Clear noted this perverse result and concluded that crime must decline again when massive numbers of people are incarcerated. In other words, the relationship is cubic, not quadratic. As shown in Figure 2, the upward sloping line of the "U" slopes downward again. The result is a curve containing a "U" followed by an upside-down "U."

Since the reverse relationship, the responsiveness of incarceration to crime, is the result of governmental policy, it can be represented as linear in crime. The two curves appear in Figure 2, where the function for incarceration crosses the line for crime only once. As indicated by arrows, it is a stable equilibrium. (The arrows come from the functions underlying the two lines in Figure 2.) The equilibrium describes the stability of American imprisonment before 1970 shown in Figure 1. And all other advanced economies have stayed in such an equilibrium.

A cubic equation can have multiple equilibria when combined with a linear relation. If government policy reduces the slope of the linear relation, that is, if incarceration becomes more responsive to factors other than crime, the two curves can cross again, as shown in Figure 3. If Blacks are incarcerated for being Black, as opposed to being imprisoned for committing a crime, 
then the flatter linear relations in Figure 3 are more accurate than the single linear relation in Figure 2. As you might expect, the presence of multiple equilibria is dependent on the nature of governmental policy (Temin, 2018).

\section{History}

American society was in turmoil in the late 1960s. There were many high-profile assassinations of prominent people: John F. Kennedy in 1963 and Martin Luther King and Robert F. Kennedy in 1968. And there were race riots in many cities around the country: Harlem in 1964, Watts and Chicago in 1965 and Newark, Detroit and many other cities in 1967. Crime suddenly had risen all over. People were scared, and President Johnson appointed a National Advisory Commission on Civil Disorders, known as the Kerner Commission, in 1967 to help understand what was going on (Temin, 2021).

The Kerner Commission's Report concluded pithily: "What white Americans have never fully understood - but which the Negro can never forget - is that white society is deeply implicated in the ghetto. White institutions created it, white institutions maintain it, and white society condones it." The report concluded that policies should be adopted to move toward a single integrated society, but it was rushed into publication for political reasons and soon was overcome by concern over the Vietnam War (Kerner Commission, 1968, Chapter 16, Summary).

Instead of reversing this divisive trend, public policies intensified it by seeking additional imprisonment and longer incarceration for African Americans. This blindness was the origin of our current dilemma. Blacks rioted in the late 1960s in opposition to the growing Vietnam War and in frustration at the slow-moving gains they expected from the Civil Rights Movement. White flight stranded Blacks who moved north into Black center cities where social services were inadequate. The growth of the Drug War segregated Blacks instead of integrating them (Boustan, 2007).

The riots passed into history, but the urge to incarcerate led to mass incarceration in a process described by John Ehrlichman, President Nixon's domestic-policy adviser, in 1994: “The Nixon campaign in 1968, and the Nixon White House after that, had two enemies: the antiwar left and black people. You understand what I'm saying? We knew we couldn't make it illegal to be either against the [Vietnam] war or black, but by getting the public to associate the hippies with marijuana and blacks with heroin, and then criminalizing both heavily, we could disrupt those communities. We could arrest their leaders, raid their homes, break up their meetings, and vilify them night after night on the evening news. Did we know we were lying about the drugs? Of course, we did (Baum, 2016)."

H. R. Haldeman, Nixon's Chief of Staff, confirmed Nixon's attitude in his diaries. He described President Nixon views as follows: "P [Nixon] emphasized that you have to face the fact that the whole problem is really the blacks. The key is to devise a system that recognizes this while not appearing to. Pointed out that there has never in history been an adequate black nation, and they 
are the only race of which this is true. Says Africa is hopeless. The worst there is Liberia, which we built (Haldeman, 1994; Associated Press, 1994)."

Nixon's racism found its outlet in severe penalties for Blacks and hippies, although the penalties were much harsher for Blacks. Federal laws were expanded in state laws that ranged from threestrike laws to harsh penalties for possession of small amounts of marijuana. In Figure 3, government policy shifted from i1 to i2.

The crack epidemic of the 1980s led to policy changes that intensified the movements of the 1970s. The changes originated in an attempt to reform the judicial process to lower prison terms, promote consistency among courts and encourage alternative sanctions to prison. By the time various bills were combined and transformed into the Sentencing Reform Act of 1984, however, the aim had shifted to become a part of Nixon's War on Drugs and the national toughness on crime. It was followed by a series of laws that translated the new, tough approach into detailed sentencing guidelines (Lynch, 2016, Chapter 2).

The Anti-Drug Abuse Act of 1986 mandated a minimum sentence of five years without parole for possession of five grams of crack cocaine, while it mandated the same only for possession of 500 grams of powder cocaine. This 100:1 disparity clearly criminalized Black people because they favored crack cocaine far more than whites. Nixon's War on Drugs became a New Jim Crow, depriving African Americans of their civil rights and economic freedom. The result was that one out of three Black men could expect to spend time in prison by 2000. The new Jim Crow disrupted Black communities all across the country. Almost all Black families had a member in prison or knew of a friend in prison. The racial disparity between whites and Blacks under the new rules can be seen in the contrast of between this estimate and the estimated one of seventeen white men who could expect incarceration. Very few white people know imprisoned people. This act shifted the incarceration line in Figure 3 from i2 to i3 (Alexander, 2010; Bonczar, 2003; Lynch, 2016, 26).

Congress determined the shape of another crime bill a decade later. President Clinton proposed to allay fears of the 1980 s crime wave with a bill that would put 100,000 more police on the streets and expand prisons. These punitive measures were offset by a ban on assault weapons and a variety of social programs aimed at crime prevention and social intervention. But the social programs were stripped from the bill, and Clinton signed the resulting bill containing only the punitive parts (Wheelock and Hartmann, 2007; Raphael and Stoll, 2013).

These political decisions increased the responsiveness of incarceration to crime, and the decline in the slope of the incarceration rate caused it to intersect the crime rate curve at several places. The curve shifted from "i1" to "i2" initially as shown in Figure 3, preserving a single crossing of the curves. But as increasingly strong laws mandated Blacks to be more vulnerable, the curve moved from "i2" to "i3," leading to three crossings. Only two of these crossings are stable, 
presenting the United States with a choice of few prisoners or mass incarceration. As shown in Figure 1, incarceration rose as criminal justice changed.

Glenn Loury expressed this transition in words: "Imprisonment rates have continued to rise while crime rates have fallen because we have become progressively more punitive; not because crime has continued to explode (it hasn't), not because we made a smart choice, but because we have made a collective decision to increase the rate of punishment (Loury, 2008, 7)".

Elizbeth Hinton noted that Johnson's War on Poverty was accompanied by his War on Crime. The War on Drugs became President Reagan's expansion of policing and incarceration in response to the crack epidemic. In her words, "The extension of military power into domestic law enforcement primarily functioned to seal the United States from 'undesirable influences' from the rest of the Western Hemisphere. ... With the militaristic turn in domestic law enforcement already underway and patrol at the nation's border established, the administration led Congress in renewing the War on Drugs (Hinton, 2016, 311-12)."

The laws shifted the judicial process from courtrooms to offices where prosecutors put pressure on accused people to plea-bargain. The threat of harsh minimum sentences gives prosecutors the option of reducing the charge to a lesser one if the accused is reluctant to languish in jail — if he or she is unable to make bail and face the possibility of long years in prison. The shift of power was eased by the pattern of financing; public prosecutors are paid by localities, while the costs of prisons are borne by states. The number of inmates grew primarily from the increase in convictions rather than the length of sentences. "Few people in the criminal justice system are as powerful, or as central to prison growth, as the prosecutor." (Stuntz, 2011, 286; Pfaff, 2017, 127)

The increasing power of public prosecutors contributed also to the falling slope of the incarceration rate. The number of line prosecutors that try cases roughly doubled between 1970 and 2007, while the number of public defenders did not rise. The result was increasing power of public prosecutors who used their power to seek plea bargains; jurisprudence moved from the courtroom to the offices of public prosecutors. Prosecutors used their power to increase the sensitivity of incarceration to the crime rate, dramatically reducing the slope of the incarceration rate (Pfaff, 2017, 129).

There now are three places where the two curves intersect. They all represent equilibria, but the middle crossing is unstable. One is to the left with less incarceration, and the other is to the right with mass incarceration. But the dynamics of politics pushed for more incarceration, representing the urge to incriminate more and more. Incarceration increased until it came to rest at a new stable equilibrium. The new equilibrium can be seen in the stability of the incarceration rate for the past few years. There was no mention of any program to move from this position in the presidential campaigns of 2016 and 2020. Although we do not yet have as many years of observations like those that showed the stability of the equilibrium before 1970, this model predicts that we will stay at the new equilibrium for the foreseeable future (Temin, 2018). 
The disparity in the minimum sentences for crack and powder cocaine were reduced from 100:1 to $28: 1$ in 2010, when the illegal possession of crack cocaine was increased to 28 grams (1 ounce) by the Fair Sentencing Act of that year. Penalties for simple possession of crack cocaine also were reduced. The larger disparity had continued for almost half a century, supported by the backlash from the Civil Rights Movement, Nixon's Southern Strategy, and the belief that Black prisoners were inherently criminal - not ordinary people who had done criminal things. But after even forty years, the difference between crack and powder cocaine were not eliminated (Raphael and Stoll, 2013, 115-20).

A First Step Act was signed in early 2019 that allowed drug offenders in federal prisons to be freed early. It freed a few thousand prisoners from federal prisons that contain only one-tenth of the millions of prisoners in state and federal prisons. Ninety percent of the freed prisoners were Black. Even though this bill had support from both the ACLU and the Koch brothers, there was no second step (Fandos, 2018; Editorial Board, 2019).

Mass incarceration has mushroomed to the point where we look more like the kleptocracies of Eastern Europe and the Middle East than the democracies of Western Europe. We need to focus on ways to remove the equilibrium at mass incarceration. The model indicates that it will be hard to dislodge ourselves from the new equilibrium of mass incarceration.

\section{Evidence}

The effect of these laws and convictions can be seen in Figure 4, which shows the incarceration rate for Blacks and whites with different incomes at a single date in 2010. The upper line for Black incarceration rates is above the rate for whites for all incomes, but much further above for poor families. This clear difference shows that race was dominant, even though income also was important in the aftermath of growth of a well-educated Black elite in the Civil Rights

Movement. College educated Black men are far safer from drug convictions than working-class Black men, although still more likely to be incarcerated than white men (Chetty and Hendren, 2020a, b).

The American criminal justice system now holds almost 2.3 million people in 3 thousand local jails, 2 thousand state prisons, 200 juvenile correction facilities and 100 federal prisons. Blacks are three times as likely to be sent to prison as whites as 40 percent of prisoners are Black while Blacks are only 13 percent of the population. In addition, three quarters of jail prisoners have not been convicted of any crime; they are poor and often Black victims of our monetary bail system. That is why the line for Blacks in Figure 4 slopes down as family income increases. The war on drugs is the center of mass incarceration, and nonviolent drug convictions dominate federal convictions. However, most state prisoners are convicted of other offenses, and an additional 3.6 people are on probation (Sawyer and Wagner, 2020).

The evolution of mass incarceration can be seen in Table 1, which shows the cumulative risk of imprisonment of whites and Blacks of different education levels up to 1979 and 1999. Instead of 
a snapshot at one time, Table 1 shows the risk of risk of Black and white cohorts of different education, which is highly correlated with the household income shown in Figure 4. The table shows that white men's risk of going to prison remained low for all groups, although it increased for high school dropouts from 4 percent to 11 percent in these 20 years. In contrast to this rough stability, the risk for Black high school dropouts multiplied more than three times from 17 percent to 59 percent. The risk for Black high school graduates increased from 7 percent to 18 percent. And the risk for Black men with some college fell slightly. Table 1 shows that we fit Garland's definition of mass incarceration, massively incriminating poor and uneducated Black youths, and it indicates how the estimate of one in three Black men goes to jail is concentrated among high school dropouts.

The increase in prison inmates was not the result of an increase in crime. Crimes of young men whose imprisonment rose actually fell in the late 1980s and 1990s. The crime rates for drug dealing, harming property and stealing all fell. Instead, the rise in incarceration resulted from the political history just recounted (Western 2006, chapter 2).

The rise of mass incarceration affected Black families and communities. A study of the education of families where one-fifth of fathers were incarcerated and one-third of fathers who lacked a high-school degree were incarcerated revealed that children of incarcerated fathers had significantly larger behavior problems at all stages of childhood. The largest effects came when fathers were incarcerated during early childhood and adolescent years. These children were stigmatized at an early age as Blacks rather than as children of incarcerated fathers-for few children could even pronounce "incarcerated" (Johnson, 2009).

Another study spelled out the varied ways in which mass incarceration affects the lives of poorly educated Blacks. Incarcerated poor men find it hard to find good jobs, and their annual incomes are about one-third lower than non-convicts with similar education. Incarceration also inhibits the formation of stable two-parent families, which pool resources, socialize and supervise children, and provide networks of mutual aid. Mass incarceration diminishes the ability of incarcerated men from enjoying these social resources. The study concluded, "First, that mass imprisonment has significantly sealed the social immobility of poor blacks. Second, if we view the effects of the prison boom in the context of its causes, mass imprisonment has significantly subtracted from the gains of African American citizenship hard won by the civil rights movement (Western 2006, 163, 191)."

These findings have been confirmed by research on income differentials between Blacks and white men. In the heart of the Great Recession, almost 40 percent of prime-age Black men at the bottom of the income distribution where mass incarceration takes its toll were unemployed, compared with less than 20 percent of white men. Blacks at the top of their income distribution found that their incomes reduced the Black-white income gap, largely through greater college employment (Bayer and Charles, 2018; Western, 2018; Temin, 2021). 
Blacks and Latinos suffered the sharpest fall in wealth in the 2008 financial crisis and the Great Recession. The median wealth of white households fell from $\$ 135,000$ to $\$ 113,000$ between 2005 and 2009, while the median wealth of Black households fell from $\$ 12,000$ to $\$ 6,000$ and Latino households' wealth fell from $\$ 18,000$ to $\$ 6,000$. White households' wealth fell less than 20 percent. Black households' wealth fell by half, and Latino wealth, by two-thirds. As of 2018, Blacks were two and half times more likely to be in poverty as whites (Pew Research, 2011, 13; EPI, 2020).

As mass incarceration grew, it put pressure on state governments. About ninety percent of prisoners are in state prisons. And the fiscal weight of these prisoners put pressure on state budgets which reduced education expenditures. States universities lost funds whenever there was a fiscal crisis, and primary and secondary schools lost funds more smoothly. Mass incarceration thus lowered economic growth in two ways. Prisoners were not educated while in prison, although we do hear of occasional prison schools. More importantly, the funds for the schooling of all the other children has been reduced. Prisons were being closed as 2021 started, but not to save prisoners; the prisons were being closed to protect the guards from COVID-19 (Mitchell and Leachman, 2014; Temin, 2017 (Derr, et al., 2021).

The fate of many Black boys today is shown by a study that followed a sample of prisoners in Boston, MA, for a year after they were released from prison. Two-thirds of the people in this sample had only poverty incomes, and half made less than $\$ 6,000$, which researchers conceptualize as deep poverty. These felons are not included in prison or poverty data as they are too poor and scattered to be in a general sample. It is worth quoting the conclusions on race: “Africans and Latinos make up less than one-quarter of the city's population but were about 75 percent of the formerly incarcerated sample of the reentry study. The white respondents we interviewed were mostly in their forties or older, were high school graduates, and had histories of addiction, mental illness, and homelessness. The black and Latino respondents were more often in their twenties and more likely to be high school dropouts with little work history. They experienced more unemployment, and their incomes were only half the incomes of whites after incarceration. Because kin connections were stronger among black and brown respondents compared to whites, Black and brown families were drawn into the orbit of the prison through visits, phone calls, canteen payments, and the provision of housing after release. In short, the new racial inequality was visible in Boston through the association between the incarceration of young black men and the deep economic disadvantage woven into the structure of their economic opportunities (Western, 2018, 176)."

We are in a New Jim Crow period, echoing the Jim Crow laws of the first Gilded Age that lasted to the Second World War. Michelle Alexander made this parallel over a decade ago, and further research has confirmed her analogy. The Republican party has been intent on restricting Blacks from voting. Black people, are having trouble voting now as they have had in the past. The barriers come from bad laws as in the past and also from more modern hardships as well. Florida 
voters passed a popular constitutional amendment granting ex-felons the vote by a two-to-one margin. The Supreme Court then upheld the Florida Republican legislative institution of debt repayments - a new kind of poll tax - for voting by ex-felons who had been granted voting rights. A new Jim Crow indeed (Alexander, 2010; Baker, M., 2020; Liptak, 2020; Wines, 2020).

\section{Choices}

The model shows that policies to reduce the rate of incarceration must pass laws that reduce the rate at which crime changes incarceration. In Figure 3, the function for government policy needs to shift only from "i3" to "i2" to destroy the mass incarceration equilibrium. We do not need to recapture "i1," which shows government policy before the War on Drugs, but only to get to "i2." Then the model predicts we will approach the incarceration levels of similar countries over time.

A start was made in the Fair Sentencing Act of 2010, but more legislative progress does not look likely any time soon. Democratic administrations were only slightly better than Republican ones in the development of mass incarceration as described in the history recounted above and confirmed by statistical analysis. Very few states were willing to let prisoners go for their safety after prisons were shown to be coronavirus hotspots. And police hostility to Blacks appears to be the result of the urban riots of the 1960s that stimulated Nixon to form his War on Drugs (Western, 2006, 72; Gertner, 2020; Tully, 2020; Barker, Keller and Eder, 2020).

An alternative approach is to reduce the incentives for public prosecutors to cut plea deals that send accused people to prison. We could increase funds for public defenders to link the unopposed actions of prosecutors, and we could use monetary incentives to induce prosecutors to focus more on serious defendants. "It will not be easy. Reform will require prodigious and sustained effort, a both the grassroots and political elite levels (Hinton, 2018; Pfaff, 2017, 205)."

Education appears to be the most promising way for African Americans to avoid the racism that they normally face. Like voting, education is handled at the state level, and progress will be uneven. We had a Black president and now have a Black vice-president, but poor Black boys still face a life of poverty and imprisonment. We must push for integrated schools and special care for minority students to allow future generations to escape from the ills of mass incarceration. Stampp repeated Myrdal's conclusion that Blacks are very diverse. And we now have both rich and poor Blacks, who typically are educated and school dropouts as well (Stampp. 1941).

Teachers have been low paid for close to half a century. When wages began to stagnate around the time that the rate of incarceration began to rise, teachers' wages also stopped rising with the national economy. Teachers, were doubly hit as they mostly were women who saw their opportunities for high-paying jobs open up. The result shifted teaching from a well-paid job to a low paid job that could be represented by a movement from one equilibrium to another, as in the 
model discussed here. The result has been a lower quality of teachers in this new teacher market (Temin, 2002).

The problems created by this history appear at all levels of education today. Head Start began in 1965 as part of the Civil Rights Movement. The need for early education grew out of this history because Black parents typically had little education to pass on to their children. As many studies have shown, an absence of books at home places beginning students at a sharp disadvantage at school. Head start helped beginning grade scholars, but the effects initially appeared to disappear over the next few years.

James Heckman, a Nobel Prize winning economist, wrote, "The accident of birth is a principal source of inequality in America today." He drew three lessons for social policy from this observation. Life today depends on cognitive skills, these skills develop in early childhood, and early education can improve the chances of children of disadvantaged parents. We need to have programs like Head Start to equalize the opportunities for all American children (Heckman, 2013).

Head Start's effects wear off if not supported by subsequent education. And Black children now frequently are denied good education, as shown by a student claiming "Multiplication is for white people." We need more integrated schools to dispel such defeatism. Rucker Johnson showed that Black achievements in integrated schools are not made at the expense of white learning, which is unaffected. And David Kirp told how community colleges are using personal interventions to help discouraged students to graduate. But even progressive states like Massachusetts have racially separated schools (Heckman, 2013; Johnson, 2019; Kirp, 2019; Delpit, 2012; Scharfenberg, 2020).

Head Start does not guarantee college admission. Head Start is the beginning of a long process that needs personal attention along the way. With generations of relatives who have been denied education, children often think they are unable to learn. When a teacher asked a young boy to go to the board to work out a math problem, he replied that he was mentally retarded and not supposed to be in regular school. The teacher responded that someone else's opinion did not have to become his reality. This encouragement freed the student to progress in school and graduate in due time (Delpit, 2012, 79; Temin, 2017).

Black students need stimulus and encouragement. The student needs to be shaken out of his customary reluctance to think by supportive teachers who lead him or her into new areas. The problem created by current political advocates of arming teachers to combat school shootings is that armed teachers represent authority and move students into command behavior where they cannot think for themselves. Only a friendly teacher can stimulate a student into independent thought without scaring him or her to death. 
The results of all this history are sharpest in college education. Almost half of undergraduates leave college before graduation. Graduates are burdened by student debt. Eighty percent of Black students graduate with college debt, and they have on average seventy percent larger debt than white students. Debt is particularly prevalent in for-profit colleges that attract students by their ease in getting government Pell grants and providing for daily costs of studying.

As in earlier education, attention by teachers is all important. An experiment at the University of Texas put low scoring SAT students into smaller sections of some classes with more peer tutors and faculty advisors. The proportion of students graduating rose from 50 to 70 percent, and poor and minority students made the biggest gains. But getting faculty to help poor and minority students is hard as most professors want to publish more than they want to encourage poor Black and brown students. Professors normally value their own advancement above the advancement of their students (Kirp, 2019, Chap. 5; Tough, 2019, Chap. 6; Zimmerman, 2020).

These two proposals, easing criminal punishment and encouraging Black education are complementary. They should be pursued at the same time. The data show that mass incarceration is devastating for poor Black boys; better education would help them avoid their entry into the imprisoned world. And schools and prisons are fighting for the same state funds. Reducing prison costs would free up funds for more education for urban Black boys. This paper argues for an integrated program to help poor Black boys: fewer convictions and more educational degrees are complements. We need to pursue an integrated anti-racist program.

Larry Krasner, Philadelphia's District Attorney, is a pioneer for judicial reform at the local level of enforcement, a promising path that will take a long time to become national even if it is taken up by other district attorneys, as it has started to be in New York, New Jersey and Boston.

Krasner instructed his 300 Assistant District Attorneys to start their plea bargaining at the lower end of mandatory sentencing guidelines, to decline charges for marijuana possession independent of its weight, to decline charges for sex workers who have two or fewer prior convictions, and to lower retail theft under $\$ 500$ to the lowest possible misdemeanor. It has taken a generation to get into mass incarceration; it may take as long to get out of it (Ewing, 2018; Fulop and Hudnut, 2018; Mueller, 2018).

The growth of private prisons also makes judicial reform harder by adding another interested group to the political process. The number of people housed in private prisons has increased by almost half since 2000 while the total number of prisoners rose only ten percent; private prisons now house over eight percent of all US prisoners. There are only three large companies operating these prisons, and they give generously to Republican candidates. The Obama administration started to phase out private prisons; the Trump administration reversed this policy. Wardens receive incentives for staying within budgets, but they are not penalized when there is violence or even if prisoners die. The growth of private prisons adds to the difficulty of escaping from the mass incarceration equilibrium (Williams and Oppel, 2018). 


\section{Conclusions}

Mass incarceration reduces the educational success of children of inmates and family formation by ex-felons when they are released. The effects of mass incarceration distinguish members of the Black urban community from white suburban communities. They lead whites to steer clear of Blacks, and increase segregated living. And, as Nixon intended, urban Blacks are stigmatized.

These results show the effect of the discrimination against poor Black boys as the second Gilded Age continues. What would it cost to fix or even ameliorate these conditions? Do not ask the rich people of the Gilded Age. Their only interest is in low taxes, and successive Republican administrations since 1960 reduced taxes for the Forbes 400 wealthiest people, while poor Blacks suffered under their radar. That is why an integrated program - reduce prison time and expand education time - is most promising. Transfer money from prisons to schools instead of seeking to get more taxes.

American education is in bad shape due to inadequate funding for a generation. Badly-paid teachers do their best, but they need to be supported with higher pay, newer buildings, better settings for students to learn. Incarcerated Blacks however attracted more funds as prisons expanded to accommodate mass incarceration. A transfer of state funds from prisons to schools would be a win-win combination. It also would help economic growth to have more educated people who could get jobs in our new digital economy and even discover new ways to improve it. This switch is needed even more after Education Secretary Betsy DeVos, who neglected the needs of students in neighborhoods with high incarceration rates, retired. It will take a lot of resources to counter her attempts to kill public education (Editorial Board, 2021).

This Gilded Age is like the last Gilded Age in its efforts to keep African Americans out of the mainstream economy. The two ages have kept Black Americans poor for over a century. A few have joined the mainstream as a result of educational achievements, but the number remains small. Blacks without much education are stigmatized as convicts and deprived of family life as ex-convicts. Their children do badly in school and may well reproduce their fathers' experiences. The United States would be better off if the very rich did not exploit the racism of many whites to maintain their political power (Mitchell and Leachman, 2014).

I end on a moral note. Massachusetts recently freed a man jailed for nearly 30 years on a wrongful conviction. Attorneys on both sides agreed he was innocent, but it took a Supreme Court justice to free the prisoner, helped by the coronavirus epidemic. The rapper will be under house arrest until a new trial can take place, as the initial trial is now considered wrongful. The Boston District Attorney said that she would drop the case if a new trial were called (Fox, 2020).

Glenn Loury invoked John Rawls' theory of social justice to consider such a miscarriage of justice. Rawls' theory was that social justice should be considered behind a veil of ignorance of who we are, and that inequality should be justified only if it helps the most disadvantaged 
members of society. A man wrongly imprisoned for almost 30 years is severely disadvantaged, and each of us could have been born that man, imprisoned for his adult life, as Heckman said. Mass incarceration that gives rise to this kind of wrongful imprisonment is immoral (Rawls, 1971; Loury, 2008).

Mass incarceration gives rise to wrongful imprisonment of many innocent people, not only the man just described. Massachusetts based its drug convictions during the first decade of the 2000s on two drug labs, one in Boston and one in western Massachusetts. These labs were underfunded and without much supervision. The principal testers, young white women named Dookhan and Farak, became addicted to the drugs they supposedly were verifying and failed miserably to test each sample accurately. They were sentenced to 1.5- and 2-years confinement after their addiction became known (Carr, 2020).

After many requests and suits by defense attorneys, state prosecutors eventually turned over their records to the defense. New attorney generals then dropped cases and freed tens of thousands of drug prisoners. Further suits may well result in hundreds of thousands of prisoners being declared innocent of drug offenses and freed. Almost all of these wrongful convictions were for drug possession only.

Newspaper stories did not dwell on the effects of imprisonment on imprisoned individuals, although a Netflix series about the drug scandal identified and described one or two of them. Western's research described above reveals the great harm done by incarceration. There is no metric for immorality. The moral argument about one prisoner extends to many, many others as well. The criminal justice system in the progressive state of Massachusetts is highly corrupt and immoral. And, as Judge Rakoff argues, the problem is national (Arnett and Mulvihill, 2021; Mulvihill and Arnett, 2021; Rakoff, 2021). 


\section{References}

Alexander, Michelle. 2010. The New Jim Crow: Mass Incarceration in the Age of Colorblindness. New York: New Press.

Arnett, Dugan, and Maggie Mulvihill, 2021. "Suffolk District Attorney Rachael Rollins to drop charges, convictions in tens of thousands of cases tied to troubled state lab." Boston Globe, March 22.

Associated Press, 1994, "Haldeman Diary Shows Nixon Was Wary of Blacks and Jews." New York Times, May 18.

Baker, Mike. “The Facts About Mail-In Voting and Voter Fraud.” New York Times, June 22, 2020.

Barker, Kim, Michael H. Keller and Steve Eder, 2020. "How Cities Lost Control of Police Discipline." New York Times, Dec. 22.

Baum, Dan. 2016. "Legalize It All: How to Win the War on Drugs." Harper's Magazine, April.

Bayer, Patrick, and Kerwin Kofi Charles, 2018. "Divergent Paths: A New Perspective on Earnings Between Black and White Men since 1940." Quarterly Economic Journal 133, 1455101.

Bonczar, Thomas P. 2003. "Prevalence of Imprisonment in the U. S. Population, 1974-2001." U.S. Department of Justice, Bureau of Justice Statistics, August, NCJ 197976.

Carr, Erin Lee, 2020. "How to Fix a Drug Scandal,” Netflix Serial.

Carson, E. Ann, and Elizabeth Anderson. 2016. "Prisoners in 2015." U.S. Department of Justice, Bureau of Justice Statistics, December, NCJ 250229.

Clear, Todd R. 2007. Imprisoning Communities: How Mass Incarceration Makes Disadvantaged Neighborhoods Worse. New York: Oxford University Press.

Delpit, Lisa, 2012. "Multiplication is for White People: Raising Expectations for Other People's Children. New York: New Press.

Derr, Brendon, Rebecca Griesbach and Danya Issawi. 2021. "States Are Shutting Down Prisons as Guards are Crippled by Covid-19. New York Times, Jan. 1.

Editorial Board, 2019. "At Long Last, a Measure of Justice for Some Drug Offenders." New York Times, June 11.

Editorial Board, 2021. “The Wreckage Betsy DeVos Leaves Behind.” New York Times, Jan. 2. 
EPI, 2020. "Black Workers face two of the most lethal preexisting conditions for coronavirusracism and economic inequality." Washington, DC: Economic Policy Institute.

Ewing, Maura, "Philadelphia's New Top Prosecutor Is Rolling out Wild, Unprecedented Criminal Justice Reforms," Slate, March 14, 2018. Available at: https://slate.com/news-andpolitics/2018/03/phillys-new-top-prosecutor-is-rolling-out-wild-unprecedented-criminal-justicereforms.html.

Fagan, Jeffery, Valerie West \& Jan Holland, "Neighborhood, Crime, and Incarceration in New York City," 36 Colum. Hum. Rts. L. Rev. 71 (2004).

Fandos, Nicholas , 2018, “Senate Passes Bipartisan Criminal Justice Bill.” New York Times, Dec. 18.

Fox, Jeremy C., 2020. "Man Jailed for nearly 30 years is released.” Boston Globe, December 24. Fulop, Steven M., and Jacob V. Hudnut. "Pressing Pause on Pot Convictions." New York Times, July 29, 2018.

Garland, David, 2001. "Introduction: The Meaning of Mass Imprisonment," in Garland (ed.), Mass Imprisonment: Social Causes and Consequences. London: Sage Publications.

Gertner, Nancy, 2020. "Coronavirus can mean a death sentence to prisoners.” Boston Globe, May 5.

Haldeman, H. R., 1994. The Haldeman Diaries: Inside the Nixon White House. New York: G. P. Putnam's Sons.

Heckman, James J., 2013. Giving Kids a Fair Chance (A Strategy That Works) Cambridge: MIT Press.

Hinton, Elizabeth, 2016. From the War on Poverty to the War on Crime: The Making of Mass Incarceration in America. Cambridge: Harvard University Press.

Hinton, Elizabeth, 2018. "Turning Prisons into Colleges," New York Times, March 8.

Johnson, Rucker T. 2009. "Ever-Increasing Levels of Incarceration and the Consequences for Children," in Raphael and Stoll, pp. 177-206.

Johnson, Rucker C., 2019. Children of the Dream: Why School Integration Works. New York: Basic Books.

Kerner Commission. 1968. The 1968 Report of the National Advisory Commission on Civil Disorders. New York: New York Times Company.

Kirp, David, 2019. The College Dropout Scandal. New York: Oxford University Press. 
Liptak, Adam, 2020. "Supreme Court Allows Restrictions on Voting by Ex-Felons." New York Times, July 16.

Loury, Glenn C., 2007. Race, Incarceration, and American Values. Cambridge: MIT Press.

Lynch, Mona. 2016. Hard Bargains: The Coercive Power of Drug Laws in Federal Court. New York: Russell Sage Foundation.

Mitchell, Michael, and Michael Leachman, 2014. "Changing Priorities: State Criminal Justice Reforms and Investments in Education," Center on Budget and Policy Priorities." October 28.

Mueller, Benjamin, 2018. "Mayor and Some Prosecutors Move to Curb Marijuana Arrests," New York Times, May 15.

Mulvihill, Maggie, and Dugan Arnett, 2021. "More cases tied to scandal-plagued drug lab could be tossed in 'nightmare scenario' for state's criminal justice system." Boston Globe, March 26.

Pew Research Center, 2011. "Wealth Gaps Rise to Record Highs Between Whites, Blacks and Hispanics.” Washington, DC: July 26.

Pfaff, John F. 2017. Locked In: The True Causes of Mass Incarceration-and How to Achieve Real Reform. New York, Basic Books.

Rakoff, Jed S., 2021. Why the Innocent Plead Guilty and the Guilty Go Free. New York: Farrar, Strauss and Giroux.

Raphael, Steven, and Michael A. Stoll (eds.). 2009. Do Prisons Make Us Safer? The Benefits and Costs of the Prison Boom. New York: Russell Sage Foundation.

Raphael, Steven, and Michael A. Stoll. 2013. Why Are So Many Americans in Prison? New York: Russell Sage Foundation.

Rawls, John, 1071. A Theory of Justice. Cambridge: Harvard University Press

Sawyer, Wendy, and Peter Wagner, 20202. "Mass Incarceration: The Whole Pie 2020." Prison Policy Initiative press release, March 24. Available at http://www.prisonpolicy.org/reports/pie2020.html

Scharfenberg, David, 2020. "Massachusetts' public schools are highly segregated. It's time we treated that like the crisis it is." Boston Globe, December 11.

Stamp, W. J., 1941. The Mind of the South. New York: Knopf.

Stuntz, William J., 2011. The Collapse of American Criminal Justice. Cambridge, MA: Harvard University Press. 
Temin, Peter, 2002. "Teacher Quality and the Future of America," Eastern Economic Journal, 28 (Summer), 285-300.

Temin, Peter, 2017. The Vanishing Middle Class. Cambridge: MIT Press.

Temin, Peter, 2018. "The Political Economy of Mass Incarceration: An Analytical Model," International Journal of Political Economy (Vol. 47, no. 3 (Fall 2018).

Temin, Peter, 2021. Never Together: The Economic History of a Segregated America. New York: Cambridge University Press.

Tully, Tracey, 2020. “About 20\% of N.J. Prisoners Could Be Freed to Avoid Virus.” New York Times, July 30.

Western, Bruce, 2006. Punishment and Inequality in America. New York: Russel Sage Foundation.

Western, Bruce, 2018. Homeward: Life in the Year After Prison. New York: Russel Sage Foundation.

Wheelock, Darren, and Douglass Hartmann. 2007. "Midnight Basketball and the 1994 Crime Bill Debates: The Operation of a Racial Code," Sociological Quarterly, 48, 315-42.

Williams, Timothy, and Richard A. Oppel, Jr., "Escapes, Riots and Beatings. But States Can't Seem to Ditch Private Prisons," New York Times, April 10, 2018. 


\section{Table 1}

\section{Cumulative Risks of Imprisonment by 1979 and 1999}

\begin{tabular}{|c|c|c|c|c|c|c|}
\hline Birthdates & HS & HS & HS or & HS or & Some & Some \\
& Dropouts & Dropouts & GED & GED & College & College \\
\hline $1945-49$ & 4 & 17 & 1 & 7 & 1 & 6 \\
\hline $1965-69$ & 11 & 59 & 4 & 18 & 1 & 5 \\
\hline
\end{tabular}

Source: Western, 2006, 27, Figure 1.4. 
Figure 1

Incarceration rate, 1925-2009

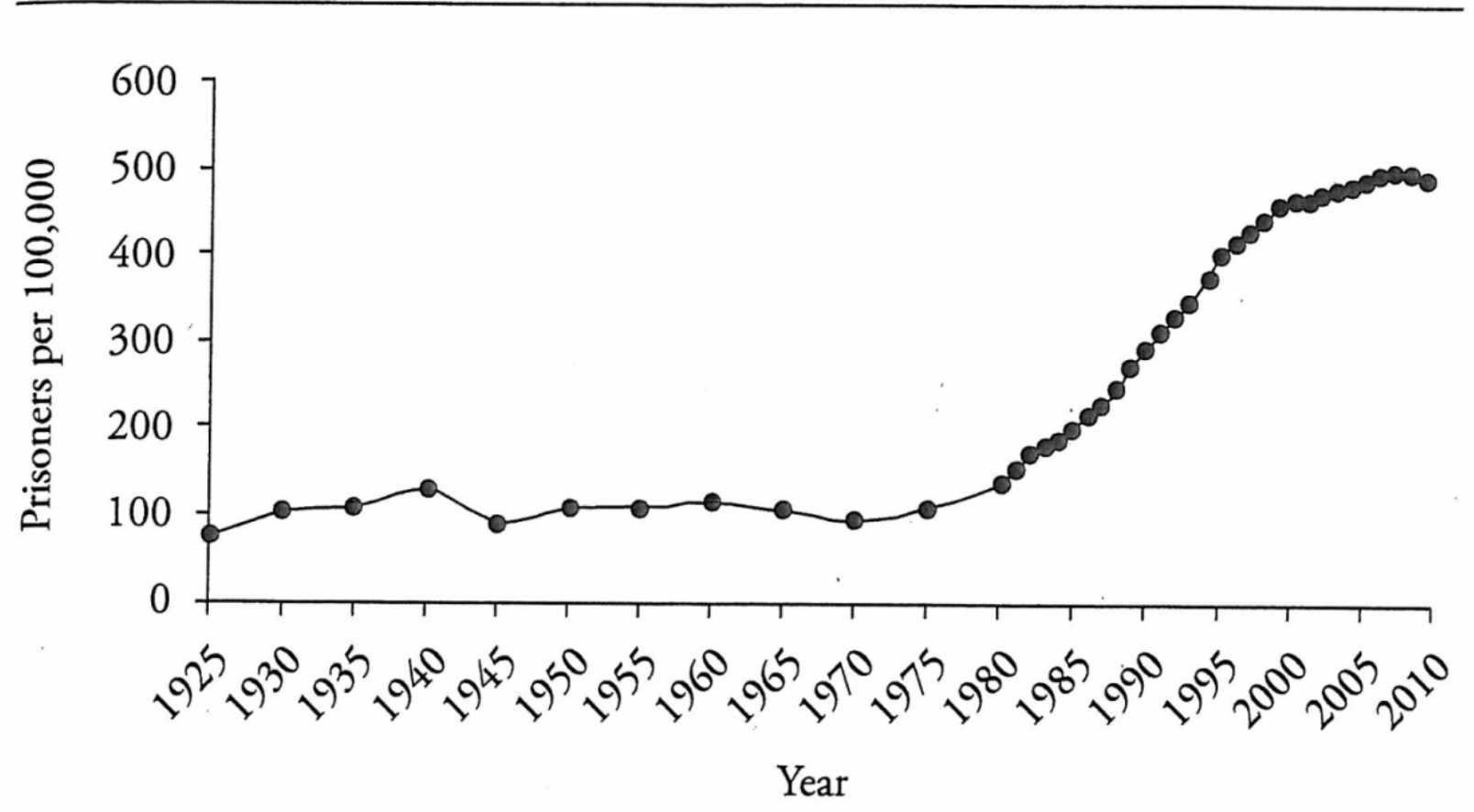

Source: Authors' compilation based on Bureau of Justice Statistics, National Prisoner Statistics (various years).

Source: Raphael and Stoll, 2013, p. 5. 
Figure 2

\section{Curves showing the initial stable equilibrium}

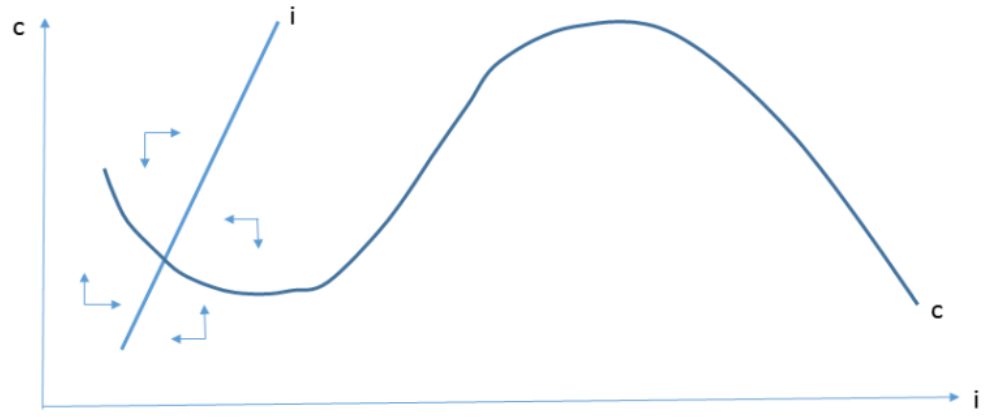

Figure 3

Curves showing two stable equilibria

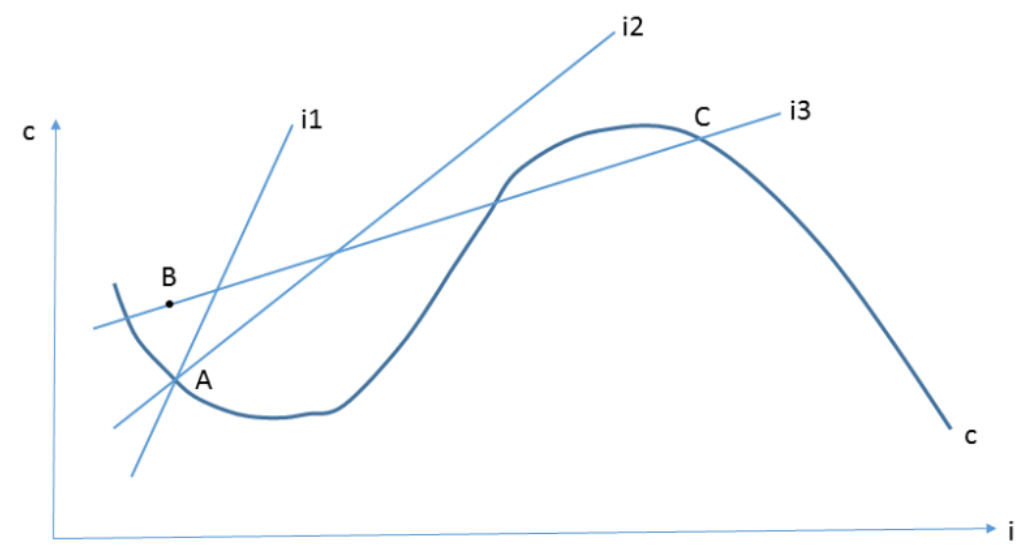




\section{Figure 4}

Incarceration rates by income and race, 2010

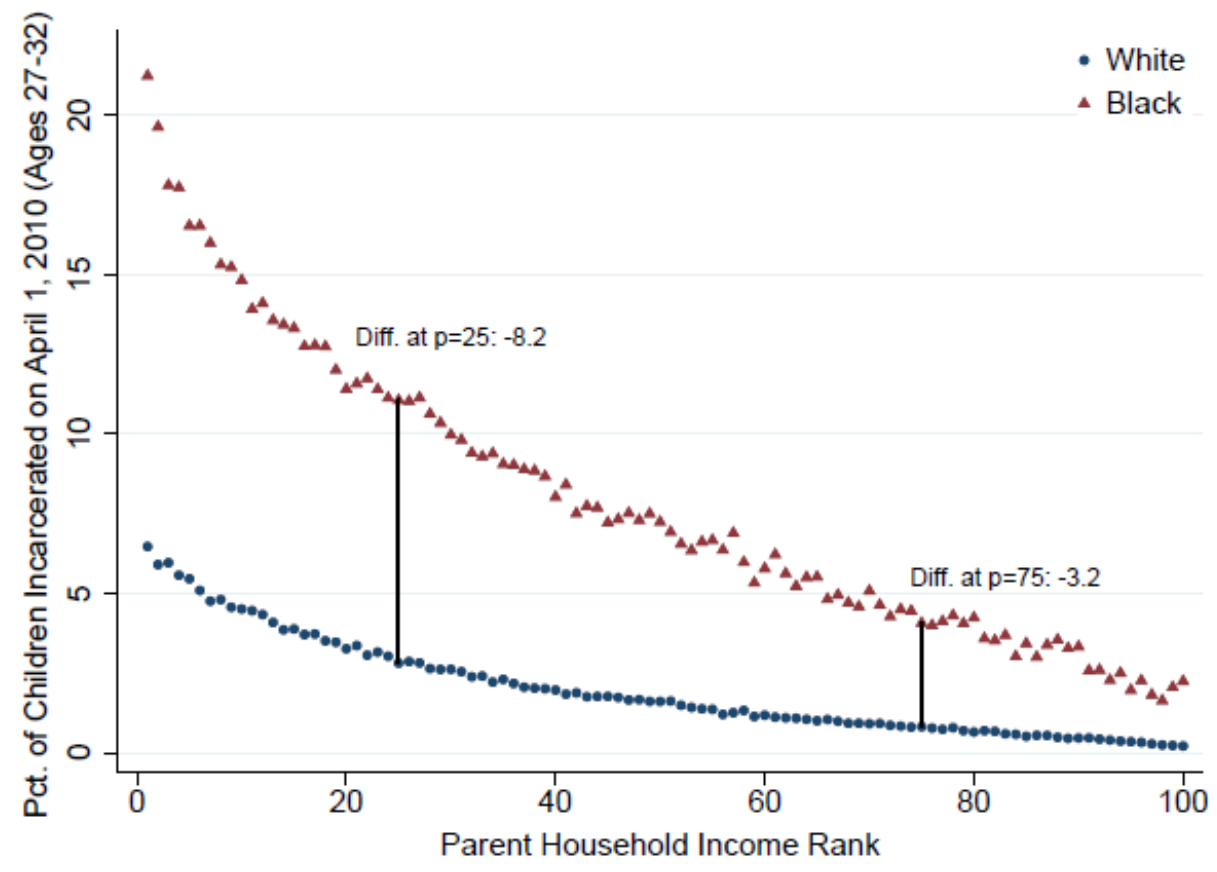

Source: Chetty, 2018a. 